\title{
The Effect of Comparison of Concrete Using Tangkiling Sand and Kapuas SAND on the Compressive Strength of Concrete
}

\section{Pengaruh Perbandingan Beton yang Memakai Pasir Tangkiling dan Pasir Kapuas Terhadap Kuat Tekan Beton}

\author{
Whendy Trissan, S.T, M.Sc ${ }^{1)}$ Yongki Pratomo ${ }^{2)}$
}

1), 2) Pendidikan Teknik Bangunan, Fakultas Keguruan dan Ilmu Pendidikan Universitas Palangka Raya Kampus UPR Tunjung Nyaho Jl. H. Timang, 73111A

e-mail:whendy_t@fkip.upr.ac.id

\begin{abstract}
In general, concrete fillers are made from materials that are easily obtained, easily processed and have the durability and strength that are very much needed in a particular construction of coarse and fine aggregates, each region would have different aggregates as the main ingredients in making concrete. The research conducted aims to determine how the optimum compressive strength value of the concrete produced from the addition of Kapuas Sand to the concrete mixture.

In this research, Kapuas Sand is used as a fine aggregate enhancer. The percentage variation of Kapuas red sand used in this study varies, namely $0 \%, 25 \%, 50 \%, 75 \%$, and $100 \%$. Concrete mixture planning using SNI 03-2834-2000. The test uses cylindrical specimens with a height of $30 \mathrm{~cm}$, a diameter of $15 \mathrm{~cm}$ with a total sample of 10 cylinders for each addition of Kapuas Sand, so that the total specimens are 50 cylinders. Testing is carried out at the age of 14 and 28 days in the Laboratory of Building Engineering Education Study Program, Faculty of Teacher Training and Education, University of Palangka Raya.

The results of the compressive strength of concrete using a mixture of Kapuas Sand at 28 days $0 \% 25 \%$, $50 \%, 75 \%$ and, $100 \%$ respectively were $24.71 \mathrm{MPa}, 21.79 \mathrm{MPa}, 25.36 \mathrm{MPa}, 23.3 \mathrm{MPa}$ and $.22 .62 \mathrm{MPa}$. This result shows the compressive strength value of concrete in concrete mix with a percentage of $50 \%$ that is equal to $25.36 \mathrm{MPa}$ while the compressive strength of normal concrete is $24.71 \mathrm{MPa}$ so that the compressive strength of concrete is $2.66 \%$ of normal concrete compressive strength with age concrete compressive strength 28 days.
\end{abstract}

Keywords: Kapuas Sand, Tangkiling Sand, Concrete Compressive Strength

\begin{abstract}
ABSTRAK
Secara umum bahan pengisi beton terbuat dari bahan-bahan yang mudah diperoleh, mudah diolah dan mempunyai keawetan serta kekuatan yang sangat diperlukan dalam suatu konstruksi khususnya agregat kasar dan agregat halus, setiap daerah tentu memiliki agregat yang berbeda-beda sebagai bahan utama dalam pembuatan beton. Penelitian yang dilakukan bertujuan untuk mengetahui berapa nilai kuat tekan beton optimum yang dihasilkan dari penambahan Pasir Kapuas pada campuran beton.

Dalam penelitian ini, Pasir Kapuas digunakan sebagai penambah agregat halus. Persentase variasi Pasir merah kapuas yang digunakan dalam penelitian ini bervariasi yaitu $0 \%, 25 \%, 50 \%, 75 \%$, dan $100 \%$. Perencanaan campuran beton menggunakan SNI 03-2834-2000. Pengujiannya menggunakan benda uji berbentuk silinder dengan ukuran tinggi $30 \mathrm{~cm}$, diameter $15 \mathrm{~cm}$ dengan jumlah sampel 10 silinder untuk setiap variasi penambahan Pasir Kapuas, sehingga total benda uji 50 silinder. Pengujian dilaksanakan pada umur 14 dan 28 hari di Laboratorium Program Studi Pendidikan Teknik Bangunan Fakultas Keguruan dan Ilmu Pendidikan Universitas Palangka Raya.

Hasil penelitian kuat tekan beton yang mengunakan campuran Pasir Kapuas pada umur 28 hari 0\% 25\%, $50 \%, 75 \%$ dan, $100 \%$ secara berturut-turut yaitu sebesar 24,71 MPa, 21,79 MPa, 25,36 MPa, 23,03 MPa dan, 22,62 MPa. Hasil ini menunjukan nilai kuat tekan beton pada campuran beton dengan persentase $50 \%$ yaitu sebesar 25,36 MPa sedangkan kuat tekan beton normal 24,71 MPa sehingga terjadi penambahan kuat tekan beton sebesar $2,66 \%$ dari kuat tekan beton normal dengan kuat tekan beton umur 28 hari.
\end{abstract}

Kata Kunci : Pasir Kapuas, Pasir Tangkiling, Kuat Tekan Beton

\section{PENDAHULUAN}

Secara umum bahan pengisi beton terbuat dari bahan-bahan yang mudah diperoleh, mudah diolah dan mempunyai keawetan serta kekuatan yang sangat diperlukan dalam suatu konstruksi. Dari sifat yang dimiliki beton itulah menjadikan beton sebagai bahan alternatif untuk dikembangkan baik bentuk fisik maupun metode pelaksanaanya. 
Di setiap daerah tentu memiliki agregat yang berbeda-beda dengan yang lain tetapi fungsinya tetaplah sama yaitu sebangai penyusun beton, khususnya agregat kasar dan agregat halus sebagai bahan utama dalam pembuatan beton. Untuk mengetahui hal tersebut, maka penulis melakukan penelitian ini kuat tekan beton yang menggunakan Pasir Tangkiling dengan Pasir Kapuas.

Beton adalah suatu material yang menyerupai batu yang diperoleh dengan membuat suatu campuran yaitu semen, pasir, kerikil dan air untuk membuat campuran tersebut menjadi keras dalam cetakan sesuai dengan bentuk dan dimensi struktur yang diinginkan. Kumpulan material tersebut terdiri dari agregat yang halus dan kasar. Semen dan air berinteraksi secara kimiawi untuk mengikat partikel-partikel agregat tersebut menjadi suatu massa padat (George Winter, 1993).

Pada umumnya beton terdiri dari $\pm 15 \%$ semen, \pm $8 \%$ air, $\pm 3 \%$ udara, selebihnya pasir dan kerikil. Campuran tersebut setelah mengeras mempunyai sifat yang berbeda-beda, tergantung pada cara pembuatannya. Perbandingan campuran, cara pencampuran, cara mengangkut, cara mencetak, cara memadat-kan, dan sebagainya akan mempengaruhi sifat-sifat beton (Wuryati Samekto, 2001). Sifat beton meliputi mudah diaduk, disalurkan, dicor, dibentuk, tanpa menimbulkan pemisahan bahan susunan pada adukan dan mutu beton yang disyaratkan oleh konstruksi tetap dipenuhi (Daryanto, 1994).

Agregat halus didefinisikan sebagai material granular, misalnya pasir, kerikil, batu pecah, dan kerak tungku besi yang dipakai bersama-sama dengan suatu media pengikat untuk membentuk mortar atau beton semen hidrolik atau adukan. Agregat yang butirbutirnya lebih kecil dari 1,2 $\mathrm{mm}$ disebut pasir halus, sedangkan butir-butir yang lebih kecil dari $0,075 \mathrm{~mm}$ disebut silt, dan yang lebih kecil dari 0,002 $\mathrm{mm}$ disebut clay (SK SNI T-15-1991-03). Persyaratan mengenai proporsi agregat dengan gradasi ideal yang direkomendasikan dalam standar ASTM C 33/ 03 "Standard Spesification for Concrete Aggregates". Sedangkan untuk syarat modulus halus butir agregat halus berkisar antara 1,5 - 3,8 (SNI 03 - 1750 - 1990). Persyaratan lainnya mengacu pada SK SNI S-04-1989-F.

Pasir pasang adalah pasir yang lebih halus dari pasir beton ciri-cirinya apabila dikepalkan pasir akan mengumpal tidak kembali lagi ke semula. Jenis pasir ini lebih murah dibandingkan dengan pasir beton. Pasir pasang biasanya dipakai untuk campuran pasir beton agar tidak terlalu kasar sehingga bisa dipakai untuk plesteran. Pasir Tangkiling yang ada di Kalimantan Tengah tepatnya di Jalan Tjilik Riwut Km. 36 Kecamatan Tangkiling yang sering disebut dengan Pasir Tangkiling ini telah digunakan secara luas sebagai bahan bangunan. Pasir Tangkiling merupakan material lepaslepas sehingga diantara material tersebut tidak

BALANGA: Jurnal Pendidikan Teknologi dan Kejuruan ISSN 2338-426X memiliki gaya ikat satu dengan yang lainnya, serta memiliki ukuran pasir 0,0625 mm - $2 \mathrm{~mm}$. Pasir Tangkiling memiliki butir-butir lebih besar tektur lebih kasar, warna berbeda dibandingkan dengan Pasir Kapuas.

Pasir Kapuas adalah pasir yang diperoleh dari sungai yang merupakan hasil gigisan batu-batuan yang keras dan tajam, pasir jenis ini cukup baik antara $(0,063 \mathrm{~mm}-5 \mathrm{~mm})$ sehingga merupakan adukan yang baik untuk perkerjaan bangunan. (Drs.Daryanto,2008). Di sepanjang tepian Sungai Kapuas dan Kapuas Murung banyak kita temukan tempat-tempat yang menyediakan pasir sebagai bahan bangunan. pasir Kapuas ini diperoleh dengan penyedotan yang dilakukan di kedua sisi sungai tersebut. Dari kapal penyedot pasir tersebut Dialihkan ke tempat penampungan yang ada di pingiran sungai.

Kuat tekan adalah kemampuan beton untuk dapat menerima gaya per satuan luas. Nilai kekuatan beton diketahui dengan melakukan pengujian kuat tekan terhadap benda uji silinder ataupun kubus pada umur 28 hari yang dibebani dengan gaya tekan sampai mencapai beban maksimum. Beban maksimum didapat dari pengujian dengan menggunakan alat compression testing machine.(Tri Mulyono, 2004).

Kuat tekan beton merupakan sifat penting dalam kualitas beton dibandingkan dengan sifat-sifat yang lain. Kekuatan tekan beton ditentukan oleh pengatuaran dari perbandingan semen, agregat kasar dan halus, air dan bebagai jenis campuran. Pada SNI 031974-2000, kuat tekan beton dapat dihitung dengan persamaan berikut:

$$
\begin{aligned}
& f^{\prime} c=\frac{P}{A} \\
& \text { dengan: } \\
& \mathrm{f}^{\prime} \mathrm{c}=\text { Kuat Tekan Beton (MPa) } \\
& \mathrm{P} \quad=\text { Beban Maksimum (N) } \\
& \mathrm{A} \quad=\text { Luas penampang }\left(\mathrm{mm}^{2}\right)
\end{aligned}
$$

Perbandingan dari air semen merupakan faktor utama dalam menentukan beton. Semakin rendah perbandingan air semen semakin tinggi kekuatan tekannya. Satuan jumlah tertentu air diperlukan untuk memberikan aksi kimiawi dalam pengerasan beton, kelebihan air meningkatkan kemampuan pekerjaan (mudahnya beton untuk dicor) akan tetapi menurunkan kekuatan dalam. (Chu Kia Wang dan C.G Salom, 1990).

\section{METODE PENELITIAN}

Untuk memberikan gambaran lebih jelas tentang jalannya penelitian, maka dapat dilihat pada Gambar 1. Peralatan yang digunakan dalam penelitian ini terbagi tiga sesuai dengan kegunaannya yaitu sebagai berikut:

1. Peralatan yang digunakan dalam pemeriksaan bahan penyusun beton adalah sebagai berikut: timbangan, satu set saringan, alat pemisah, talam dan kuas, keranjang kawat 
2. Peralatan yang digunakan dalam pembuatan benda uji adalah: mesin pengaduk campuran beton (mixer cement), cetakan benda uji berbentuk silinder dengan ukuran tinggi $30 \mathrm{~cm}$ dan diameter $15 \mathrm{~cm}$, satu set alat slump test untuk mengukur tingkat kemudahan pengerjaan dan konsistensi adukan beton, sekop, cetok, ember, talam untuk menuangkan adukan beton segar.

3. Sedangkan peralatan yang digunakan dalam perawatan dan pengujian benda uji adalah: bak perendam berisi air yang digunakan untuk perawatan benda uji dan pengamatan (curing) dengan cara merendam seluruh permukaan beton, mesin uji kuat tekan dan tarik belah beton.

Adapun tahapan penelitian tersebut adalah sebagai berikut:

\section{a. Pemeriksaan Bahan}

Pemeriksaan bahan dilakukan di Laboraturium Beton Program Studi Pendidikan Teknik Bangunan Jurusan Teknologi dan Kejuruan Fakultas Keguruan dan Ilmu Pendidikan Universitas Palangka Raya yang meliputi: pemeriksaan gradasi agregat kasar bertujuan untuk menentukan pembagian butir (gradasi) agregat kasar yang mengacu pada SNI 03-1968-1990. Pemeriksaan uji kepipihan agregat kasar bertujuan untuk mengontrol jumlah butiran yang dapat digunakan sesuai dengan batasan dalam spesifikasi yang menentukan kualitas agregat kasar yang akan digunakan dalam campuran dan mengacu pada RSNI T01-2005. Pemeriksaan kadar air agregat kasar bertujuan untuk memperoleh angka persentase kadar air yang terkandung dalam agregat dan mengacu pada SNI 03-1971-1990. Pemeriksaan berat jenis dan penyerapan air agregat kasar Pemeriksaan ini mengacu pada SNI-03-1969-1990. Pemeriksaan berat isi agregat kasar Pemeriksaan berat isi agregat bertujuan untuk mengetahui berat isi yang terkandung dalam agregat dan mengacu pada SNI-03-4804-1998.

\section{b. Perencanan Campuran Beton}

Perencanan campuran beton berdasarkan SNI 032834-2000, tentang tata cara pembuatan rencana beton normal. Langkah penentuan data perencanan campuran beton sebagai berikut: menentukan kuat tekan rencana $\left(f^{\prime} c\right)$, menentukan deviasi standar, menghitung persentase campuran pasir merah Kapuas, Kekuatan rata-rata yang di rencanankan, pemilihan jenis semen, menentukan jenis agregat kasar, pemilihan faktor air semen bebas dan maksimum (FAS), pemilihan nilai slump 6-18 cm, menentukan kadar air bebas, menentukan kadar semen, menentukan berat isi beton, menghitung kadar agregat halus, menghitung kadar agregat kasar, komposisi campuran, kondisi agregat dalam keadan kering (jenuh).

Benda uji dibuat berbentuk silinder dengan ukuran cetakan tinggi $30 \mathrm{~cm}$ dan diameter $15 \mathrm{~cm}$, dengan banyaknya jumlah benda uji yaitu seperti pada Tabel 1.

Perawatan dilakukan setelah beton mencapai final setting, artinya beton telah mengeras. Menurut SK SNI T-15-1990-03 perawatan benda uji dalam penelitian ini dilakukan dengan cara merendam seluruh permukaan beton segar didalam bak perendam yang berisi air, untuk mencegah terjadinya keretakan karena kehilangan air. Perawatan ini tidak hanya dimaksudkan untuk mendapatkan kekuatan tekan beton yang tinggi tetapi juga dimaksudkan untuk memperbaiki mutu dari keawetan beton, kekedapan terhadap air, ketahanan terhadap aus, dan stabilitas dari dimensi struktur.

Pengujian dilakukan dengan memberikan pembebanan pada benda uji dengan mesin uji tekan. Sampel akan diuji berdasarkan SNI 03-1974-1990, beban akan didistribusikan pada penampang beton secara merata sepanjang sumbu longitudinal.

Analisis data dalam penelitian ini menggunakan data yang diperoleh dari hasil pengujian silinder beton terhadap kuat tekan beton, yang ditampilkan dalam bentuk grafik dan tabel. Data yang ditampilkan adalah kuat tekan beton yang dihasilkan dari beberapa perbandingan beton dan umur beton selama 14 hari dan 28 hari.

\section{HASIL PENELITIAN}

Pengujian kuat tekan beton menggunakan mesin uji tekan (compression testing machine) dengan ukuran benda uji yang berbentuk silinder, tinggi $30 \mathrm{~cm}$ dan diameter $15 \mathrm{~cm}$. Pengujian dilaksanakan setelah beton mencapai umur 14 dan 28 hari. Hasil pengujian ratarata setiap benda uji dapat dilihat pada Tabel 2 dan Tabel 3.

Untuk Tabel kenaikan dan penurunan kuat tekan beton Pasir Kapuas masing-masing pada umur 14 hari dan 28 hari dapat dilihat pada Tabel 4 dan Tabel 5 . Dapat dilihat Tabel 4 dan Tabel 5 terjadinya kenaikan dan penurunan kuat tekan beton pada umur 28 hari. Untuk 0\% Pasir Kapuas sama dengan 100\% Pasir Tangkiling tidak ada kenaikan dan penurunan karena nilai kuat tekan ini sebagai acuan untuk mengetahui turun atau naik pada campuran 25\% Pasir Kapuas ditambahkan 75\% Pasir Tangkiling mengalami penurun karena campuran Pasir Kapuas berbutiran halus yang menyebabkan terjadinya penurunan pada campuran ini. Pada campuaran 50\% Pasir Kapuas ditambahkan 50\% Pasir Tangkiling mengalami kenaikan hal ini karena Pasir Tangkiling berbutir lebih besar dan kasar dibandingkan dengan Pasir Kapuas yang berbutir halus yang dapat mengimbangi dari campuran Pasir Kapuas tersebut. Pada campuran $75 \%$ Pasir Kapuas ditambahkan 25\% Pasir Tangkiling terjadinya penurunan kuat tekan hal ini disebabkan banyaknya presentase Pasir Kapuas dibandingkan Pasir Tangkiling. 


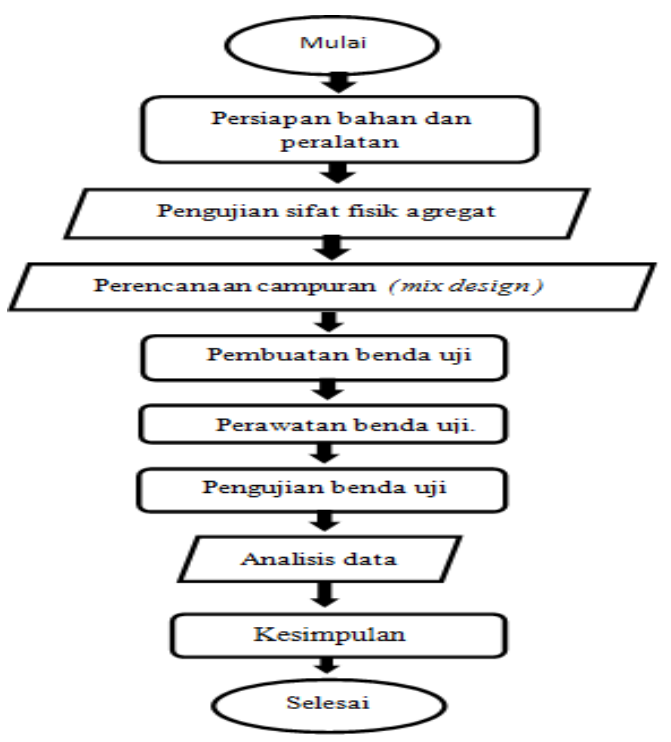

Gambar 1. Bagan Alir Penelitian

Tabel 1. Jumlah Benda Uji Untuk Setiap Campuran Beton

\begin{tabular}{cccccc}
\hline \multirow{2}{*}{ Kode sampel } & Pasir Tangkiling & $\begin{array}{c}\text { Pasir } \\
\text { Kapuas }\end{array}$ & \multicolumn{2}{c}{ Kuat tekan beton } \\
\cline { 5 - 6 } & $0 \%$ & $100 \%$ & 5 & 5 \\
\hline F1 & $25 \%$ & $75 \%$ & 5 & 5 \\
\hline F3 & $50 \%$ & $50 \%$ & 5 & 5 \\
\hline F4 & $75 \%$ & $25 \%$ & 5 & 5 \\
\hline & $100 \%$ & $0 \%$ & 25 & 5 \\
\hline
\end{tabular}

Tabel 2. Hasil Pengujian Kuat Tekan Beton Silinder Umur 14 Hari

\begin{tabular}{|c|c|c|c|c|c|c|c|}
\hline $\begin{array}{l}\text { Persentase } \\
\text { Pasir kapuas }\end{array}$ & $\begin{array}{l}\text { Benda } \\
\text { Uji (L) }\end{array}$ & $\begin{array}{c}\text { Berat } \\
\text { (kg) }\end{array}$ & Luas $\left(\mathrm{mm}^{2}\right)$ & Tinggi (mm) & $\begin{array}{l}\text { Diameter } \\
(\mathrm{mm})\end{array}$ & $\begin{array}{c}\text { Tekanan } \\
\text { (mpa) }\end{array}$ & $\begin{array}{l}\text { Rata-Rata } \\
\text { (mpa) }\end{array}$ \\
\hline \multirow{5}{*}{$0 \%$} & 1 & 12,08 & 17662,5 & 300 & 150 & 24,85 & \multirow{5}{*}{25,47} \\
\hline & 2 & 12,26 & 17662,5 & 300 & 150 & 24,57 & \\
\hline & 3 & 12,26 & 17662,5 & 300 & 150 & 25,25 & \\
\hline & 4 & 12,38 & 17662,5 & 300 & 150 & 27,97 & \\
\hline & 5 & 12,2 & 17662,5 & 300 & 150 & 24,69 & \\
\hline \multirow{4}{*}{$25 \%$} & 1 & 12,22 & 17662,5 & 300 & 150 & 22,76 & \multirow{4}{*}{23,27} \\
\hline & 2 & 12,26 & 17662,5 & 300 & 150 & 22,76 & \\
\hline & 3 & 12,24 & 17662,5 & 300 & 150 & 24,46 & \\
\hline & 4 & 12,18 & 17662,5 & 300 & 150 & 23,10 & \\
\hline \multirow{5}{*}{$50 \%$} & 1 & 12,16 & 17662,5 & 300 & 150 & 23,21 & \multirow{5}{*}{24,28} \\
\hline & 2 & 12,26 & 17662,5 & 300 & 150 & 23,21 & \\
\hline & 3 & 12,12 & 17662,5 & 300 & 150 & 24,80 & \\
\hline & 4 & 12,24 & 17662,5 & 300 & 150 & 25,59 & \\
\hline & 5 & 12,22 & 17662,5 & 300 & 150 & 24,57 & \\
\hline \multirow{5}{*}{$75 \%$} & 1 & 12,34 & 17662,5 & 300 & 150 & 22,08 & \multirow{5}{*}{23,46} \\
\hline & 2 & 12,38 & 17662,5 & 300 & 150 & 22,08 & \\
\hline & 3 & 12,26 & 17662,5 & 300 & 150 & 22,99 & \\
\hline & 4 & 12,38 & 17662,5 & 300 & 150 & 24,35 & \\
\hline & 5 & 12,12 & 17662,5 & 300 & 150 & 25,82 & \\
\hline \multirow{2}{*}{$100 \%$} & 1 & 12,22 & 17662,5 & 300 & 150 & 23,55 & \multirow{2}{*}{22,67} \\
\hline & 2 & 12,18 & 17662,5 & 300 & 150 & 22,08 & \\
\hline
\end{tabular}




\begin{tabular}{|c|c|c|c|c|c|c|c|}
\hline \multirow[t]{4}{*}{$\begin{array}{l}\text { Persentase } \\
\text { Pasir kapuas }\end{array}$} & $\begin{array}{l}\text { Benda } \\
\text { Uji (L) }\end{array}$ & $\begin{array}{l}\text { Berat } \\
(\mathrm{kg})\end{array}$ & Luas $\left(\mathrm{mm}^{2}\right)$ & Tinggi (mm) & $\begin{array}{l}\text { Diameter } \\
\text { (mm) }\end{array}$ & $\begin{array}{l}\text { Tekanan } \\
\text { (mpa) }\end{array}$ & $\begin{array}{c}\text { Rata-Rata } \\
\text { (mpa) }\end{array}$ \\
\hline & 3 & 12,3 & 17662,5 & 300 & 150 & 22,76 & \\
\hline & 4 & 12,26 & 17662,5 & 300 & 150 & 22,08 & \\
\hline & 5 & 12,16 & 17662,5 & 300 & 150 & 22,87 & \\
\hline
\end{tabular}

Tabel 3. Hasil Pengujian Kuat Tekan Beton Silinder Umur 28 Hari

\begin{tabular}{|c|c|c|c|c|c|c|c|}
\hline $\begin{array}{c}\text { Persentase Pasir } \\
\text { Kapuas }\end{array}$ & $\begin{array}{c}\text { Benda Uji } \\
\text { (L) }\end{array}$ & Berat (Kg) & Luas $\left(\mathrm{mm}^{2}\right)$ & $\begin{array}{l}\text { Tinggi } \\
(\mathrm{mm})\end{array}$ & $\begin{array}{l}\text { Diameter } \\
(\mathrm{mm})\end{array}$ & Tekanan (Mpa) & $\begin{array}{l}\text { Rata- } \\
\text { Rata } \\
\text { (Mpa) }\end{array}$ \\
\hline \multirow{5}{*}{$0 \%$} & 1 & 12,30 & 17662,5 & 300 & 150 & 22,65 & \multirow{5}{*}{24,71} \\
\hline & 2 & 12,10 & 17662,5 & 300 & 150 & 24,12 & \\
\hline & 3 & 12,22 & 17662,5 & 300 & 150 & 26,04 & \\
\hline & 4 & 12,20 & 17662,5 & 300 & 150 & 24,80 & \\
\hline & 5 & 12,40 & 17662,5 & 300 & 150 & 25,93 & \\
\hline \multirow{4}{*}{$25 \%$} & 1 & 12,12 & 17662,5 & 300 & 150 & 21,06 & \multirow{4}{*}{23.16} \\
\hline & 2 & 12,14 & 17662,5 & 300 & 150 & 23,44 & \\
\hline & 3 & 12,12 & 17662,5 & 300 & 150 & 23,44 & \\
\hline & 4 & 12,24 & 17662,5 & 300 & 150 & 24,69 & \\
\hline \multirow{5}{*}{$50 \%$} & 1 & 12,16 & 17662,5 & 300 & 150 & 27,40 & \multirow{5}{*}{25,36} \\
\hline & 2 & 12,34 & 17662,5 & 300 & 150 & 25,36 & \\
\hline & 3 & 12,28 & 17662,5 & 300 & 150 & 24,12 & \\
\hline & 4 & 12,40 & 17662,5 & 300 & 150 & 23,89 & \\
\hline & 5 & 12,20 & 17662,5 & 300 & 150 & 26,04 & \\
\hline \multirow{5}{*}{$75 \%$} & 1 & 12,18 & 17662,5 & 300 & 150 & 24,23 & \multirow{5}{*}{23,03} \\
\hline & 2 & 12,32 & 17662,5 & 300 & 150 & 24,46 & \\
\hline & 3 & 12,28 & 17662,5 & 300 & 150 & 23,44 & \\
\hline & 4 & 12,44 & 17662,5 & 300 & 150 & 21,06 & \\
\hline & 5 & 12,28 & 17662,5 & 300 & 150 & 21,97 & \\
\hline \multirow{5}{*}{$100 \%$} & 1 & 12,28 & 17662,5 & 300 & 150 & 23,21 & \multirow{5}{*}{22,62} \\
\hline & 2 & 12,32 & 17662,5 & 300 & 150 & 22,99 & \\
\hline & 3 & 12,08 & 17662,5 & 300 & 150 & 22,08 & \\
\hline & 4 & 12,28 & 17662,5 & 300 & 150 & 22,65 & \\
\hline & 5 & 12,24 & 17662,5 & 300 & 150 & 22,19 & \\
\hline
\end{tabular}

Tabel 4. Kenaikan dan Penurunan Kuat Tekan Beton Pasir Kapuas Umur 14 Hari

\begin{tabular}{cccc}
\hline Pasir Kapuas (\%) & Kuat Tekan Rata-Rata (Mpa) & Naik / Turun & $\begin{array}{c}\text { Kenaikan / Penurunan Kekuatan ke 0\% } \\
\text { pasir Kapuas }\end{array}$ \\
\hline 0 & 25,47 & - & - \\
\hline 25 & 23,27 & Turun & $16,76 \%$ \\
\hline 50 & 24,28 & Turun & $4,67 \%$ \\
\hline 75 & 23,46 & Turun & $7,87 \%$ \\
\hline 100 & 22,67 & Turun & $10,98 \%$ \\
\hline
\end{tabular}

(Sumber : Hasil Perhitungan )

Tabel 5. Kenaikan dan Penurunan Kuat Tekan Beton Pasir Kapuas Umur 28 Hari

\begin{tabular}{cccc}
\hline Pasir Kapuas (\%) & Kuat Tekan Rata-Rata (MPa) & Naik / Turun & $\begin{array}{c}\text { Kenaikan / Penurunan Kekuatan ke 0\% } \\
\text { pasir Kapuas }\end{array}$ \\
\hline 0 & 24,71 & - & - \\
\hline 25 & 23,16 & Turun & $11,82 \%$ \\
\hline 50 & 25,36 & Naik & $2,66 \%$ \\
\hline 75 & 23,03 & Turun & $6,78 \%$ \\
\hline 100 & 22,62 & Turun & $8,43 \%$ \\
\hline
\end{tabular}

(Sumber : Hasil Perhitungan ) 
Pada campuran $100 \%$ Pasir Kapuas sama dengan 0\% Pasir Tangkiling mengalami penurunan karena Pasir Kapuas lebih halus dibandingkan dengan Pasir Tangkiling dan pada pasir kapuas memiliki zat organik yang lebih tinggi dibandingkan dengan Pasir Tangkiling ini salah satu faktor yang menyebabkan terjadinya penurunan kuat tekan pada Pasir Kapuas. Banyak pembaca kenapa ada 0\% Pasir Kapuas sama dengan 100\% Pasir Tangkiling, 25\% Pasir Kapuas ditambahkan 75\% Pasir Tangkiling, 50\% Pasir Kapuas ditambah 50\% Pasir Tangkiling, 75\% Pasir Kapuas ditambahkan 25\% Pasir Tangkiling dan, 100\% Pasir Kapuas sama dengan 0\% Pasir Tangkiling kenapa demikian karena dalam satu campuran yang harus tetap $100 \%$.

Pada Tabel 3, nilai kenaikan dan penurunan kuat tekan beton umur 14 hari dengan komposisi Pasir Kapuas dengan persentase 0\%, 25\%, 50\%, 75\%, dan $100 \%$ mengalami penurunan semua.

Pada Tabel 4, nilai kenaikan dan penurunan kuat tekan beton pada umur 28 hari, menunjukan bahwa dengan persentase Pasir Kapuas0\%, 25\%, 50\%, 75\%, dan, $100 \%$ yang mengalami kenaikkan yaitu pada persentase Pasir Kapuas 50\% sebesar 2,66\%

Dari data disimpulkan, ada beberapa hal yang mungkin menyebabkan tejadinya penurunan kuat tekan, yaitu:

a. Semakin banyak presentase Pasir Kapuas dalam campuran beton menyebabkan kuat tekan beton berkurang

b. Pasir Kapuas mengandung lebih banyak zat organik dibandingkan dengan pasir Tangkiling, semakain banyak kandungan zat organik dapat mengurangi kuat tekan beton

c. Ukuran butiran Pasir Kapuas lebih halus dibandingkan dengan Pasir Tangkiling

\section{KESIMPULAN}

1. Kuat tekan beton yang dihasilkan dari pengujian dengan menggunakan Pasir Tangkiling pada umur 14 hari dengan pesentase $0 \%, 25 \%, 50 \%, 75 \%$, dan, $100 \%$ secara berturut-turut sebesar25,47 $\mathrm{MPa}, 23,27 \mathrm{MPa}, 24,28 \mathrm{MPa}, 23,46 \mathrm{MPa}$ dan, $22,67 \mathrm{MPa}$

2. Kuat tekan beton yang dihasilkan dari pengujian dengan menggunakan pasir merah Kapuas pada umur 28 hari dengan persentase $0 \% 25 \%, 50 \%$, $75 \%$ dan, $100 \%$ secara berturut-turut sebesar 24,71 MPa, 21,79 $\mathrm{MPa}, 25,36 \mathrm{MPa}, 23,03 \mathrm{MPa}$ dan, 22,62

3. Kuat tekan beton optimum diperoleh pada umur pengujian 28 hari yaitu sebesar 25,36 MPa dengan presentasi Pasir Kapuas 50\% dan Pasir Tangkiling $50 \%$
4. Berdasarkan hasil penelitian semakin besar presentase Pasir Kapuas yang dicampurkan bersama dengan Pasir Tangkiling pada campuran beton akan menyebabkan berkurangnya kuat tekan (mutu beton). Hal ini disebabkan karena Pasir Kapuas mengandung lebih banyak zat organik dan butiranya lebih halus.

5. Berdasarkan hasil penelitian Pasir Tangkilng memliliki kuat tekan beton lebih besar dibandingkan dengan Pasir Kapuas.

\section{SARAN}

1. Pada saat melakukan uji gradasi material agregat kasar dan halus harus harus berhati-hati khususnya pada uji kadar lupur dan uji kadar zat organik dikarenakan alat penguji sangat rentan pecah.

2. Pada penelitian ini harus teliti dan cermat pada saat melakukan perhitungan mix design

\section{DAFTAR PUSTAKA}

Anonim (1990).SNI 03-1974-1990 Tentang Metode Pengujian Kuat Tekan Beton. Badan Standarisasi Nasional.

Anonim (2002).SNI 03-2834-2002 Tentang Tata Cara Pembuatan Rencana Campuran Beton Normal. Badan Standarisasi Nasional.

ASTM C-33. (1999). Standard Specification for Concrete Aggregates. Diunduh pada tanggal 16 Desember 2015, dari http:https://www.scribd.com/doc/243242378 /ASTM-C33-PDF

Mulyono, T., (2004). Teknologi Beton. Yogyakarta: Penerbit Andi.PBI 1971 NI-2 Bab.3 Pasal 3.4, "Agregat Kasar (Kerikil dan Batu Pecah)", Direktorat Penyelidikan Masalah Bangunan, Departemen Pekerjaan Umum dan Tenaga Listrik, Bandung..

Samekto, Wuryati., dan Rahmadiyanto, Candrayanti. (2001). Teknologi Beton. Yogyakarta: Kanisius.

SNI 03 - 1969 - 1990, Metode pengujian berat jenis dan penyerapan air agregat kasar.

SNI 03 - 1970 - 1990, Metode pengujian berat jenis dan penyerapan air agregat halus.

SNI 03-2834-2000 Tentang Tata Cara Pembuatan Rencana Campuran untuk Beton Normal

SNI 765-2012 Tentang Tata Cara Pemilihan Campuran untuk Beton Normal,Beton Berat, dan Beton Massa

SNI 1972-2008 Tentang Cara Uji Slump Beton

SNI 2493-2011 Tentang Tata Cara Pembuatan dan Perawatan Benda Uji Beton di Laboratorium

SNI 03-1974-1990 Tentang Metode Pengujian Kuat Tekan Beton 